\title{
Dysferlin regulates cell membrane repair by facilitating injury-triggered acid sphingomyelinase secretion
}

\author{
A Defour ${ }^{1}$, JH Van der Meulen ${ }^{1}$, R Bhat ${ }^{1}$, A Bigot ${ }^{2}$, R Bashir ${ }^{3}$, K Nagaraju $^{1,4}$ and JK Jaiswal ${ }^{\star, 1,4}$
}

Dysferlin deficiency compromises the repair of injured muscle, but the underlying cellular mechanism remains elusive. To study this phenomenon, we have developed mouse and human myoblast models for dysferlinopathy. These dysferlinopathic myoblasts undergo normal differentiation but have a deficit in their ability to repair focal injury to their cell membrane. Imaging cells undergoing repair showed that dysferlin-deficit decreased the number of lysosomes present at the cell membrane, resulting in a delay and reduction in injury-triggered lysosomal exocytosis. We find repair of injured cells does not involve formation of intracellular membrane patch through lysosome-lysosome fusion; instead, individual lysosomes fuse with the injured cell membrane, releasing acid sphingomyelinase (ASM). ASM secretion was reduced in injured dysferlinopathic cells, and acute treatment with sphingomyelinase restored the repair ability of dysferlinopathic myoblasts and myofibers. Our results provide the mechanism for dysferlin-mediated repair of skeletal muscle sarcolemma and identify ASM as a potential therapy for dysferlinopathy.

Cell Death and Disease (2014) 5, e1306; doi:10.1038/cddis.2014.272; published online 26 June 2014

Dysferlinopathy is a progressive muscle wasting disease, which is classified as limb-girdle muscular dystrophy type $2 \mathrm{~B}$ (LGMD2B) or Miyoshi muscular dystrophy 1, based on its muscle involvement. ${ }^{1,2}$ Dysferlin deficit leads to altered vesicle formation and trafficking, ${ }^{3,4}$ poor repair of injured cell membranes, ${ }^{5,6}$ and increased muscle inflammation. ${ }^{7,8}$ Dysferlin contains $\mathrm{C} 2$ domains that are found in $\mathrm{Ca}^{2+}$-dependent membrane fusion proteins such as synaptotagmins. ${ }^{9}$ Thus, dysferlin is thought to regulate muscle function by regulating vesicle trafficking and fusion. ${ }^{10-13}$ Dysferlin deficiency has also been implicated in conflicting reports regarding the fusion ability of dysferlinopathic myoblasts. ${ }^{4,14-16}$ With such diverse roles for dysferlin, the mechanism through which dysferlin deficiency results in muscle pathology is unresolved. As skeletal muscle-specific re-expression of dysferlin rescues all dysferlinopathic pathologies, ${ }^{17,18}$ myofiber repair has been suggested to be the unifying deficit underlying muscle pathology in dysferlinopathy. ${ }^{19}$ Repair of injured cell membranes requires subcellular compartments, which in mammalian cells include lysosomes, ${ }^{11}$ enlargeosomes, ${ }^{20}$ caveolae, ${ }^{21}$ dysferlin-containing vesicles, ${ }^{5}$ and mitochondria. ${ }^{22}$

Cells from muscular dystrophy patients that have normal dysferlin expression exhibit normal lysosome and enlargeosome exocytosis. ${ }^{23}$ However, dysferlinopathic muscle cells exhibit enlarged LAMP2-positive lysosomes, reduced fusion of early endosomes, altered expression of proteins regulating late endosome/lysosome fusion, and reduced injury-triggered cellsurface levels of LAMP1.,11,12 In non-muscle cells, lack of dysferlin reduces lysosomal exocytosis. ${ }^{24}$ These findings implicate lysosomes in dysferlin-mediated muscle cell membrane repair. In one model for lysosome-mediated cell membrane repair, $\mathrm{Ca}^{2+}$ triggers vesicle-vesicle fusion near the site of injury, forming 'membrane patch', which fuses to repair the wounded cell membrane..$^{25-28}$ In another model, lysosome exocytosis following cell membrane injury by poreforming toxins leads to secretion of the lysosomal enzyme acid sphingomyelinase (ASM), which causes endocytosis of pores in the damaged cell membranes. ${ }^{21,29,30}$ Both these models have been suggested to be involved in the repair of injured muscle cells. ${ }^{21,28}$

To examine the muscle cell pathology in dysferlinopathy, we have developed dysferlinopathic mouse and human models. Use of these models shows that a lack of dysferlin does not alter myogenic differentiation but causes poor repair of even undifferentiated muscle cells. We show that dysferlin is required for tethering lysosomes to the cell membrane. Fewer lysosomes at the cell membrane in dysferlinopathic cells results in slow and reduced lysosome exocytosis following injury. This reduction in exocytosis reduces injury-triggered ASM secretion, which is responsible for the poor repair of dysferlinopathic muscle cells. Extracellular sphingomyelinase (SM) fully rescues the repair deficit in dysferlinopathic cells and mouse myofibers, offering a potential drug-based therapy for dysferlinopathy.

\section{Results}

Dysferlin-deficient myoblasts undergo normal growth and differentiation. To characterize the role of dysferlin in myogenic cell growth and differentiation, we used two cellular

\footnotetext{
${ }^{1}$ Center for Genetic Medicine Research, Children's National Medical Center, 111 Michigan Avenue NW, Washington, DC, USA; ${ }^{2}$ Institut de Myologie, UM76 Université Pierre et Marie Curie, U974 INSERM, UMR7215 CNRS, GH Pitié-Salpétrière, 47 bd de l'Hôpital, Paris, France; ${ }^{3}$ School of Biological and Biochemical Sciences, University of Durham, Durham, UK and ${ }^{4}$ Department of Integrative Systems Biology, George Washington University School of Medicine and Health Sciences, Washington, DC, USA

*Corresponding author: JK Jaiswal, Center for Genetic Medicine Research, Children's National Medical Center, 111 Michigan Avenue NW, Washington, DC 20010, USA. Tel: + 202476 6456; Fax: + 202476 6014; E-mail: jkjaiswal@ cnmc.org

Abbreviations: LGMD2B, limb-girdle muscular dystrophy type 2B; ASM, Acid sphingomyelinase; SM, Sphingomyelinase; GFP, Green fluorescent protein; TIRF, Total internal reflection fluorescence; EDL, Extensor digitorum longus

Received 11.4.14; revised 08.5.14; accepted 20.5.14; Edited by G Raschellà
} 
models: (1) the C2C12 cell line, derived from a pool of cells with shDNA-mediated knockdown of dysferlin (C2C12shRNA), and corresponding vector control cells (C2C12), ${ }^{31}$ and (2) a primary mouse myoblast clone isolated from immortomice carrying the $\mathrm{A} / \mathrm{J}$ allele of dysferlin (dysf-KO) or the corresponding immortomice carrying normal dysferlin allele (dysf-wild type (WT)). ${ }^{32}$ Western blot analysis showed no detectable dysferlin expression in C2C12-shRNA or primary dysferlinopathic mouse myoblasts (Figures 1a and e). Following differentiation, dysferlin expression increased in the control cells, whereas dysferlinopathic cells still showed no detectable dysferlin expression (Figures 1a, b, e and f). Immunostaining of myotubes showed that as in control cells, the dysferlinopathic cells were able to form myotubes, but they lacked any detectable dysferlin expression (Figures 1c and g). Additionally, genotyping confirmed dysferlin mutation in dysf-KO myoblasts (Figure $1 \mathrm{~h}$ ).

To assess growth, we compared the doubling time for control and dysferlinopathic cells and found the times to be comparable: $17 \mathrm{~h}$ for $\mathrm{C} 2 \mathrm{C} 12$ versus $16 \mathrm{~h}$ for C2C12-shRNA cells (Figure 1d). We also found comparable doubling times for mouse myoblasts: $17 \mathrm{~h}$ for WT-dysf versus $21 \mathrm{~h}$ for dysfKO (Supplementary Figure 1A). In view of the proposed involvement of dysferlin in myogenesis through the regulation of myoblast fusion, ${ }^{31}$ we assessed the differentiation of these cells by monitoring the expression of myogenic markers, including desmin, myogenin, $\alpha$-actinin, and myosin heavy chain 3. Expression of all these myogenic markers increased similarly and steadily during the myogenic differentiation of control and dysferlinopathic cells and resulted in myotubes that were indistinguishable from each other (Figures 1b, c, f and g).

Dysferlin deficiency compromises myoblast cell membrane repair. Studies of laser-induced injury have established a role for dysferlin in sarcolemmal repair of myofibers and myotubes. 5,15 To determine whether dysferlin also regulates myoblast cell membrane repair, we used two different cell injury approaches. ${ }^{23,33}$ In the first approach, a population of cells was injured using glass beads; all the injured cells were labeled with FITC-dextran, and cells that failed to repair got labeled with FITC- and TRITC-dextran (Figure 2a). ${ }^{33}$ This approach showed that twice as many dysferlinopathic myoblasts (C2C12-shRNA: $30 \pm 2 \%$ and dysf-KO: $25 \pm 3 \%$ ) as control myoblasts (C2C12: $15 \pm 2 \%$ and dysf-WT: $11 \pm 2 \%$ ) showed a failure to repair (Figure $2 b$ ).

In the second approach, cell membrane repair kinetics were monitored following injury with a pulsed 1-photon laser in the presence of the membrane-impermeant lipid dye FM1$43 .^{22,33}$ Because cell membrane repair depends on calcium, we established the sensitivity of this assay by injuring cells in the presence or absence of calcium. In the presence of calcium, FM dye entry ceased within a minute of injury, whereas it continued even at $4 \mathrm{~min}$ in the absence of calcium (Figure 2c and Supplementary Figure 2A). Next, we assessed the repair of $\mathrm{C} 2 \mathrm{C} 12$-shRNA myoblasts in the presence of calcium. Unlike the control C2C12 cells (Supplementary Video 1), FM dye entry into C2C12-shRNA cells continued even at 4 min after injury (albeit to a lesser extent than $\mathrm{C} 2 \mathrm{C} 12$ cells injured in the absence of calcium; Figure $2 \mathrm{~d}$ and
Supplementary Figure 2B, Supplementary Video 2). This result indicates that dysferlinopathic myoblasts, although capable of repair, are less efficient than healthy myoblasts in their repair ability.

Dysferlinopathic muscle cells show reduced injurytriggered lysosomal exocytosis. In view of the dependence of cell membrane repair on lysosome exocytosis ${ }^{34}$ and dysferlin, ${ }^{5}$ we investigated lysosomal exocytosis in dysferlinopathic myoblasts. To quantify the glass bead injuryinduced increase in the cell-surface level of the lysosomal protein LAMP1, we injured myoblasts in the presence of TRITC-dextran (causing red staining of injured cells) and then probed for cell-surface LAMP1 in live cells using an antibody specific for the luminal domain of LAMP1. ${ }^{33,34}$ Using this approach, we have previously demonstrated that, independent of repair ability, cells that exocytose lysosomes show increased cell-surface LAMP1, whereas cells that fail to exocytose lysosomes do not. ${ }^{33}$ As compared with uninjured myoblasts, we detected more LAMP1 on the surface of injured myoblasts (Figure 3a). Dysferlinopathic myoblasts showed significantly reduced (35\% for dysf-KO, 30\% for C2C12-shRNA) cell-surface LAMP1 when compared with corresponding healthy controls (Figures $3 b$ and $c$ ).

To establish whether the reduction in cell-surface LAMP1 was due to a reduction in injury-triggered lysosomal exocytosis, we monitored exocytosis of individual lysosomes following laser injury. Lysosomes were labeled with the luminal marker FITC-dextran and imaged using TIRF. ${ }^{33}$ As in our previous findings with calcium agonists, ${ }^{35,36}$ we observed injury-triggered exocytosis of individual lysosomes, as demonstrated by secretion of FITC-dextran by individual Iysosomes (Figure 3d and Supplementary Video 3,4). Dysferlinopathic myoblasts undergoing repair showed a decreased number of injury-triggered exocytic events (>2-fold for dysf-KO, Figures $3 d$ and e and Supplementary Figure 1C; $20 \%$ for C2C12-shRNA, Supplementary Figure 1B). A similar deficit was also observed when these cells were triggered with calcium ionophore (Figures $3 f$ and g). These results demonstrate that reduced injury-triggered lysosomal exocytosis in dysferlinopathic cells is the result of a deficit in $\mathrm{Ca}^{2+}$-triggered lysosomal exocytosis.

In view of the patch model for cell membrane repair, we expected lysosomes to undergo $\mathrm{Ca}^{2+}$-triggered homotypic fusion to form a 'membrane patch', ${ }^{25,27,37}$ followed by one large FITC-dextran flash caused by exocytosis of the patch vesicle. However, instead of homotypic calcium-triggered lysosome fusions we observed exocytosis of individual lysosomes to the injured cell membrane (Figures $3 d-g$ ). A variant of the patch model would involve compound exocytosis of lysosomes at the site of focal injury. We therefore examined the localization of exocytic events with respect to the site of injury. Each cell was divided into two equal halves along the long axis of the cell drawn from the site of injury, and exocytic events were quantified in the two halves (near and away from the site of injury). Exocytic events were uniformly distributed throughout the cell in WT and dysferlinopathic cells (Figures $3 \mathrm{~h}$ and $\mathrm{i}$ ), indicating that lysosomemediated repair of the muscle cell membrane does not proceed by membrane patch formation. 

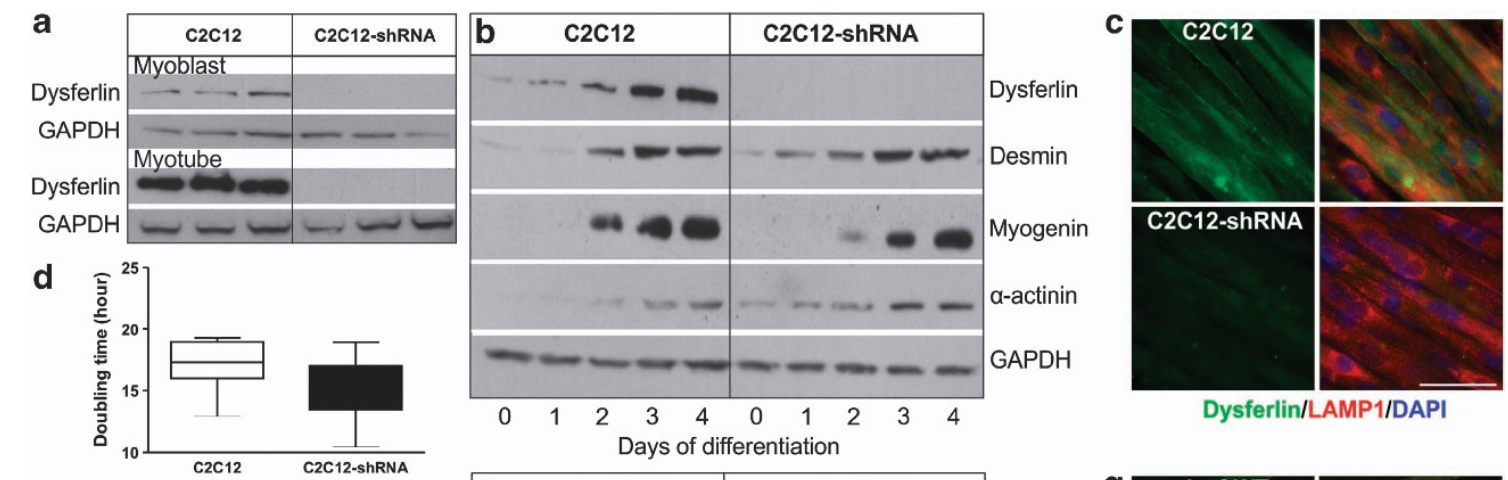

Dysferlin/LAMP1/DAPI
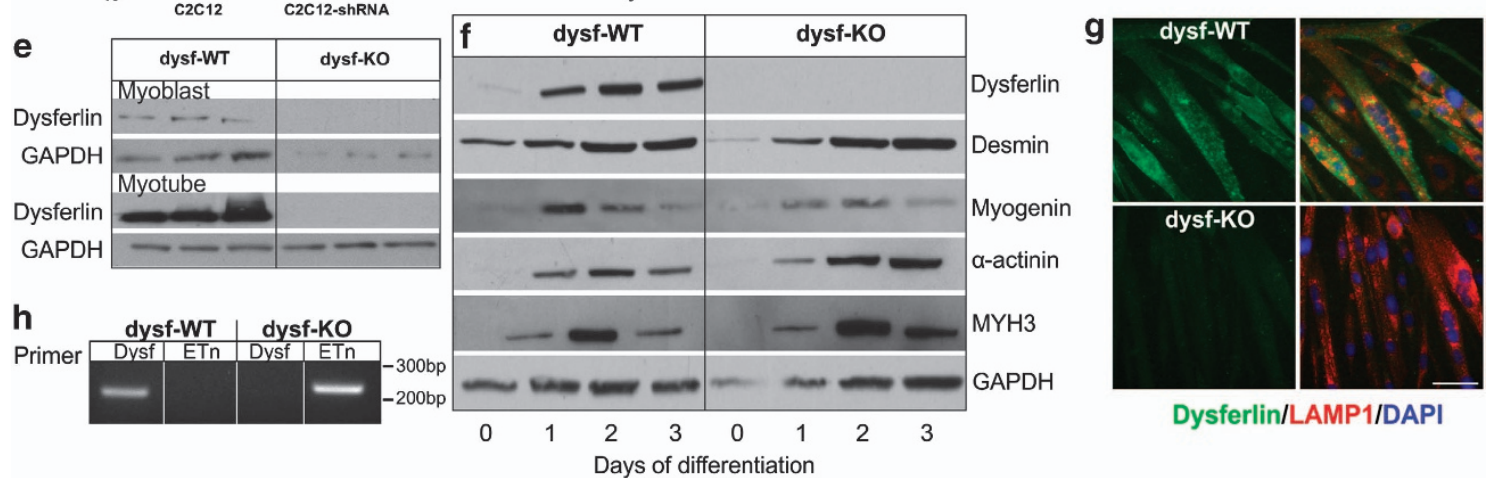

Dysferlin/LAMP1/DAPI

Figure 1 Dysferlin deficiency does not alter myoblast proliferation or differentiation. (a and e) Western blot analysis of dysferlin expression in three independent cultures each of myoblasts and myotubes (following 4 days of differentiation): (a) C2C12 and C2C12-shRNA and (e) dysf-WT and dysf-KO myoblasts. (b and f) Western blot analysis of expression of various muscle differentiation markers tested following the indicated days of differentiation in (b) $\mathrm{C} 2 \mathrm{C} 12$ and $\mathrm{C} 2 \mathrm{C} 12$-shRNA and (f) dysf-WT and dysf-KO myoblasts. (c and $\mathbf{g}$ ) Immunostaining of dysferlin (green) and LAMP1 (red) in (c) C2C12 and C2C12-shRNA and (g) dysf-WT and dysf-KO myotubes following 4 days of differentiation. Scale bar: $50 \mu \mathrm{m}$. (d) Plot showing doubling time for $\mathrm{C} 2 \mathrm{C} 12$ and $\mathrm{C} 2 \mathrm{C} 12$-shRNA myoblasts in culture during 4 days of proliferation ( $n=8$ cell cultures; error bars show the extreme values). (h) PCR analysis of genomic DNA from dysf-WT and dysf-KO myoblasts using primers to identify the presence of the full-length dysferlin allele (Dysf) and the dysferlin allele with the insertion of a retrotransposon (Etn) in the dysferlin gene

Dysferlin is required for tethering lysosomes to the cell membrane. It was primarily the lysosomes present at the cell membrane whose exocytosis was triggered by cell injury (Supplementary Video 4). Preferential involvement of cell membrane-proximal lysosomes suggested a need for rapid lysosomal exocytosis for efficient membrane repair. We therefore examined the kinetics of injury-triggered lysosomal exocytosis in healthy and dysferlinopathic cells. Lysosomal exocytosis was triggered within seconds of injury and continued over the next couple of minutes as the cells underwent repair (Figures $4 a$ and b). More than half of all exocytic events occurred within the first $15 \mathrm{~s}$ of injury, and it was the exocytosis of this pool of lysosomes that was reduced ( $\sim 3$-fold) in dysferlinopathic cells (Figures $4 a$ and $b$ ). There was no difference in the subsequent exocytic events between WT and dyferlinopathic cells, indicating that, unlike the dysferlin homologs the synaptotagmins, the lack of which prevents vesicle exocytosis, ${ }^{38}$ a lack of dysferlin delays but does not totally prevent calcium-triggered lysosomal exocytosis. This role of dysferlin in delaying (rather than blocking) lysosomal exocytosis may explain why the health of dysferlinopathic cells is poor, but they are not incapable of repair (Figures $2 b$ and $d$ and Supplementary Figure 2B).

In view of the recently identified role of dysferlin in stabilizing $\mathrm{Ca}^{2+}$ signaling in response to osmotic stress-induced myofiber injury, ${ }^{39}$ we asked whether altered lysosome exocytosis in dysferlinopathic cells is the result of a change in the kinetics of the injury-triggered $\mathrm{Ca}^{2+}$ increase in these cells. Using Fluo-4, we measured injury-triggered cytosolic $\mathrm{Ca}^{2+}$ dynamics and found no difference in the initiation and amplitude of the injury-triggered cytosolic $\mathrm{Ca}^{2+}$ increase between the control and dysferlinopathic cells (Figures 4c, d and f and Supplementary Figure 2C). However, in agreement with the slower repair of dysferlinopathic cells, an injurytriggered increase in cytosolic $\mathrm{Ca}^{2+}$ took longer to return to pre-injury values (Figures $4 \mathrm{e}$ and $\mathrm{f}$ and Supplementary Figure 2C).

Thus, in dysferlinopathic cells, reduced lysosomal exocytosis occurs in the first $15 \mathrm{~s}$ of injury despite the similar kinetics and amplitude of injury-triggered increase in cytosolic $\mathrm{Ca}^{2+}$ in WT and dysferlinopathic cells. This finding suggests that a deficit in an alternate function ascribed to synaptotagmins: vesicle docking and priming may be the basis for the delayed injury-triggered lysosomal exocytosis in cells lacking dysferlin. To test this hypothesis, we used TIRF imaging to analyze the number of lysosomes at the cell membrane in WT and dysferlinopathic cells and found a decrease of up to $30 \%$ in cell membrane-proximal lysosomes in the dysferlinopathic cells (Figures $4 \mathrm{~g}$ and $\mathrm{h}$ ). Because re-expression of dysferlin rescues the deficit in muscle cell membrane repair, ${ }^{17}$ we tested the effect of dysferlin re-expression on membraneproximal lysosomes in dysferlinopathic cells. Expression of human dysferlin in C2C12-shRNA cells restored the number of cell membrane-proximal lysosomes to WT levels 

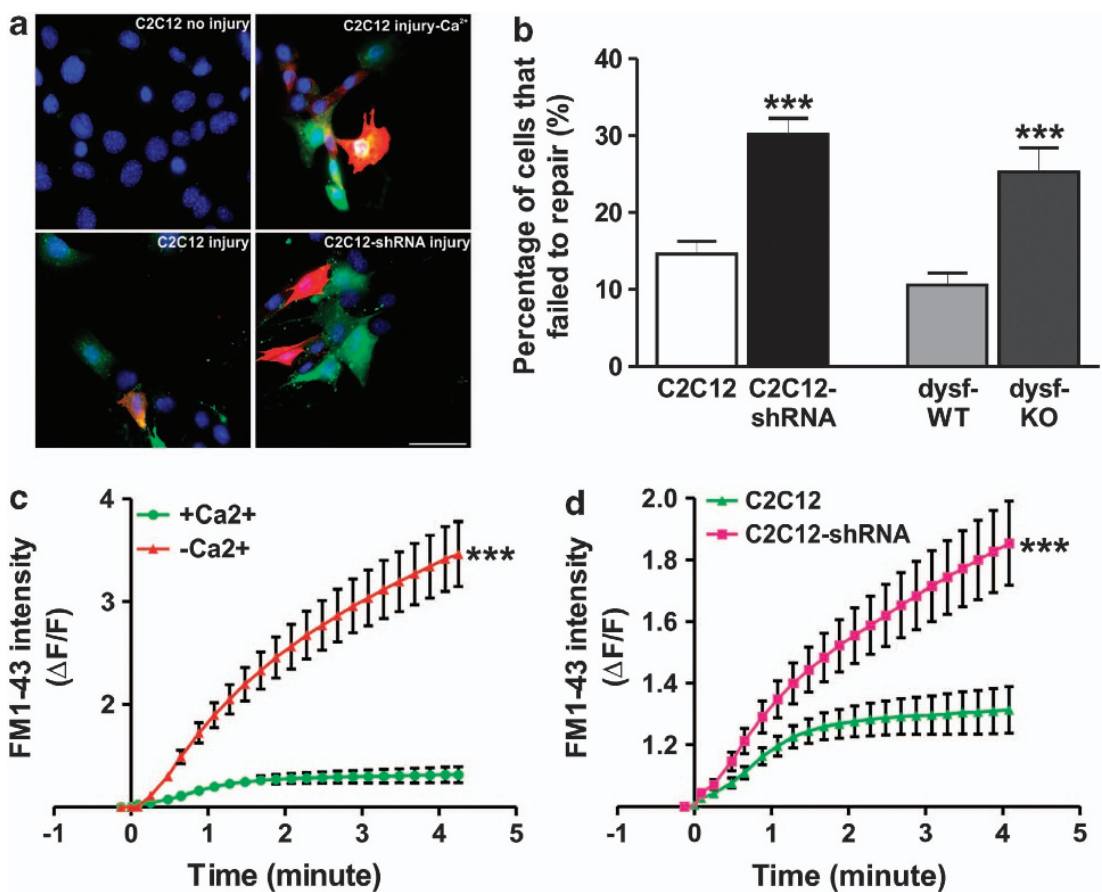

Figure 2 Dysferlinopathic myoblasts show poor cell membrane repair. (a) C2C12 cells injured in the presence of FITC-dextran (green) were allowed to undergo repair in TRITC-dextran (red) and then stained with Hoechst 33342 (blue). Uninjured cells are not labeled with dextran (upper left panel); injured cells are labeled green, and cells that failed to repair themselves are labeled red and green. Upper panels show uninjured myoblasts and myoblasts that failed to repair themselves because of a lack of $\mathrm{Ca}^{2+}$. Lower panel shows $\mathrm{C} 2 \mathrm{C} 12$ and C2C12-shRNA myoblasts injured and allowed to repair themselves in the presence of $\mathrm{Ca}^{2+}$; Scale bar: $50 \mu \mathrm{m}$. (b) Images of glass beadinjured cells were quantified (>100 cells each) and are presented as the fraction of cells that failed to show repair in the presence of $\mathrm{Ca}^{2+}$. (c) FM1-43 influx following focal laser injury in $>10$ myoblasts injured in the presence of $\mathrm{Ca}^{2+}$ shows efficient repair from laser injury; cells injured in the absence of $\mathrm{Ca}^{2+}$ do not. (d) Quantification of FM1-43 influx by time-lapse imaging of $>15$ myoblasts each following injury in the presence of $\mathrm{Ca}^{2+}$, showing poor healing of $\mathrm{C} 2 \mathrm{C} 12$-shRNA myoblasts. Data in $\mathbf{b}, \mathbf{c}$ and $\mathbf{d}$ show means \pm S.E.M.; ${ }^{* * *} P<0.001$ by unpaired Student's $t$-test

(Figure 4i). This result demonstrates that re-expression of dysferlin restores the ability of the exocytic lysosomes to be tethered to the cell membrane and correlates well with previous reports of improved sarcolemmal repair as a result of dysferlin re-expression. ${ }^{17,40}$ To determine whether dysferlin regulates lysosome tethering by being localized to lysosomes, we examined whether dysferlin localizes to LAMP1-labeled lysosomes. We found that dysferlin (and dysferlin-GFP) localized to the cell membrane, endoplasmic reticulum, and some vesicular structures but did not co-localize with lysosomes (Figures $4 \mathrm{j}$ and $\mathrm{k}$ ).

ASM is a potential drug therapy for dysferlinopathy. With no evidence to support the membrane patch model (Figures $3 \mathrm{~h}$ and i), we next examined the model describing lysosome-mediated repair of cell membranes injured by pore-forming toxins. ${ }^{29}$ According to this model, injurytriggered secretion of lysosomal ASM facilitates repair. ${ }^{29,30,41}$ In view of the lysosomal exocytosis defects in dysferlinopathic cells, this model predicts a reduced/delayed secretion of ASM by these cells and further predicts that the deficit in ASM secretion would cause poor sarcolemmal repair. To test these hypotheses, we first examined the ASM expression in healthy and dysferlinopathic $\mathrm{C} 2 \mathrm{C} 12$ cells and found their levels to be similar (Figure 5a, upper panel). Next, we asked whether, as in injury mediated by pore-forming toxins, mechanical injury would also trigger ASM secretion. Western blot analysis of culture supernatants of mechanically (scrape)-injured $\mathrm{C} 2 \mathrm{C} 12$ and $\mathrm{C} 2 \mathrm{C} 12-$ shRNA cells allowed to repair for $5 \mathrm{~min}$ showed injury-triggered ASM secretion by both types of cell. Despite their equal cellular ASM levels (Figure 5a total ASM, lower panel), dysferlinopathic cells secreted less ASM than the corresponding control cells (Figure 5a secreted ASM, lower panel). To assess mechanical injury-triggered ASM secretion, we compared ASM activity in culture supernatants of $\mathrm{C} 2 \mathrm{C} 12$ and $\mathrm{C} 2 \mathrm{C} 12$-shRNA myoblasts following repair from scrape injury. Secreted ASM activity was reduced by $70 \%$ in dysferlinopathic C2C12shRNA myoblasts, when compared with the healthy $\mathrm{C} 2 \mathrm{C} 12$ cells (Figure $5 b$ ).

The observations reported above suggested that reduced ASM secretion as a result of defective lysosome docking and exocytosis correlates with poor repair of dysferlinopathic myoblasts. Therefore, we hypothesized that providing extracellular SM to injured dysferlinopathic cells could rescue their repair deficit. To test this hypothesis, we incubated dysferlinopathic myoblasts with $2 \mathrm{U} / \mathrm{ml}$ of $S M$ and then injured them in the presence of FM dye. The presence of extracellular SM fully restored repair of C2C12-shRNA myoblasts after focal laser injury (Figure 5c, Supplementary Figure 3A, Supplementary Video 5).

To examine whether extracellular SM could serve as a potential therapy for dysferlinopathic patients, we used immortalized myoblasts derived from a LGMD2B patient. These cells lacked detectable dysferlin expression (Supplementary Figures $3 \mathrm{~B}$ and $\mathrm{C}$ ). As in the other 
a

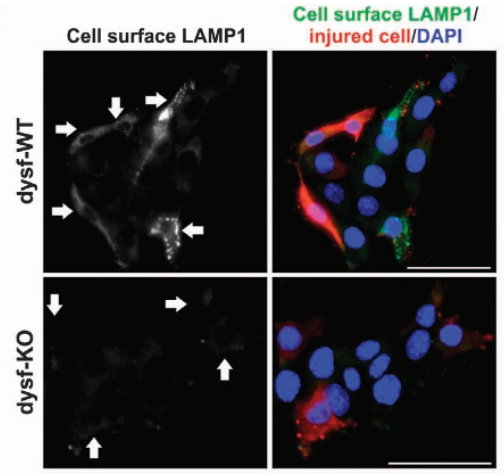

d

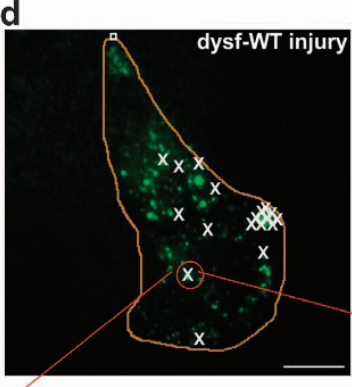

e b

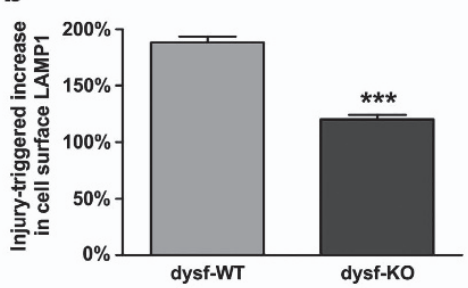

f dysf-WT ionomycin
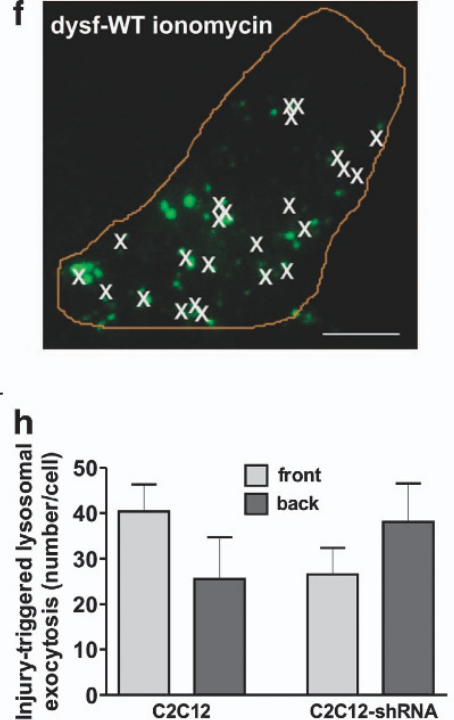

C

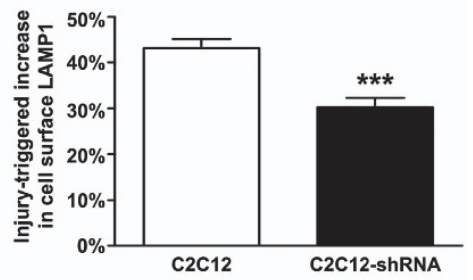

g
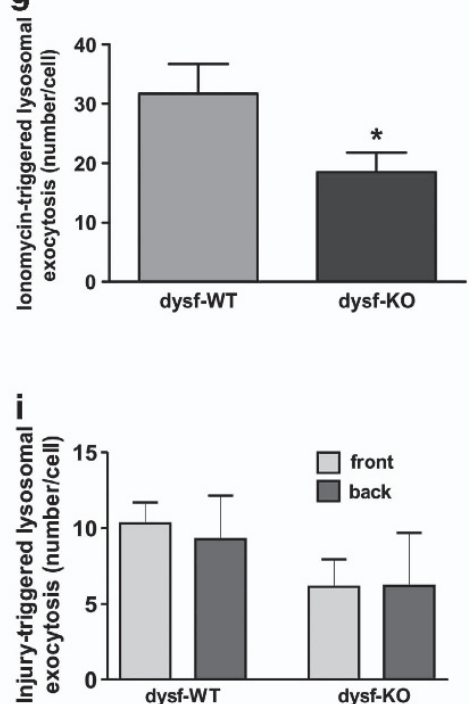

Figure 3 Dysferlin deficiency reduces injury-triggered lysosomal exocytosis. (a) dysf-WT and dysf-KO myoblasts wounded in the presence of $\mathrm{Ca}^{2+}$ by glass beads in medium containing TRITC-dextran were stained for cell-surface LAMP1 (left panel); White arrows indicate the injured cells labeled (red) by TRITC dextran. Scale bar: $50 \mu$ m. (b and $\mathbf{c}$ ) Reduced cell-surface LAMP1 staining in dysferlinopathic myoblasts following injury in the presence of $\mathrm{Ca}^{2+}$ : cell-surface LAMP1 staining was quantified for $>400$ dysf-WT, dysf-KO, C2C12, and C2C12-shRNA myoblasts each. (d and f) TIRF images showing dysf-WT myoblasts with FITC-dextran-labeled lysosomes. ' $\mathrm{X}$ ' marks the sites of lysosome fusion following (d) laser injury or (f) ionomycin treatment. The orange line denotes the cell boundary. The inset in $\mathbf{d}$ shows a zoomed view of one lysosome as it underwent fusion, releasing FITC-dextran. Scale bar: $10 \mu \mathrm{m}$. (e and $\mathbf{g}$ ) Quantification of lysosome fusions in $>13$ dysf-WT and dysf-KO myoblasts, showing a reduced number of fusion events in dysferlinopathic myoblasts following (e) laser injury (168 lysosome fusions for dys-WT and 88 for dys-KO) and (g) ionophore treatment (264 fusions for dys-WT and 112 for dys-KO). (h and i) Localization of lysosome exocytosis sites (168 for dys-WT, 88 for dys-KO, 350 for C2C12, and 385 for C2C12-shRNA) with respect to the site of injury in (h) $\mathrm{C} 2 \mathrm{C} 12$ or (i) primary myoblasts ( $n \geq 10$ cells each). Data are mean \pm S.E.M. ${ }^{*} P<0.05$ and ${ }^{* * *} P<0.001$ by unpaired Student's $t$-test

dysferlinopathic mouse myoblast models described here, myoblasts from this LGMD2B patient also formed normal myotubes (Supplementary Figure 3B). We then tested the cell membrane-repair capacity of these myoblasts and found that the patient's myoblasts did indeed have a compromised ability to repair their cell membranes (Figures $5 d$ and $e$ and Supplementary Videos 6 and 7). This cell membrane repair deficit in patient-derived myoblasts was fully reversed by treating the cells with extracellular SM (Figure 5f, Supplementary Figure S3D and Supplementary Videos 7 and 8).

To further evaluate the utility of extracellular SM treatment for improving dysferlinopathic muscle repair, we next tested the efficacy of SM treatment in rescuing the repair deficit of dysferlinopathic myofibers. For this purpose, we used extensor digitorum longus (EDL) and biceps muscles isolated from a dysferlin-deficient B6.A/J mouse. ${ }^{18}$ As compared with the EDL myofibers from parental WT (C57BL/6) mice, EDL myofibers from B6.A/J mice exhibited a significantly reduced repair ability (Figures 6a and b). EDL and biceps muscles injured following acute addition of $0.5 \mathrm{U} / \mathrm{ml} \mathrm{SM}$ (without any pre-treatment) fully rescued the repair deficit seen in the dysferlinopathic myofibers (Figures 6a-c, Supplementary Videos 9 and 10).
It has been shown that extended exposure to SM leads to mitochondrial ROS production and reduced muscle contractile force. ${ }^{42}$ However, recombinant ASM delivered in vivo (in mice) is rapidly cleared from circulation, $40 \%$ within $1 \mathrm{~min}$ of delivery. ${ }^{43}$ Therefore, we examined the effect of brief SM treatment on the contractile force, fatigue, and forcefrequency relationships in muscle from B6.A/J mice. We observed that the same SM treatment, which improved the repair ability of the myofibers $(5 \mathrm{~min}$ treatment with $0.5 \mathrm{U} / \mathrm{ml}$ $\mathrm{SM}$; Figures $6 \mathrm{a}-\mathrm{c}$ ), had no detectable effect on the specific force (Figure 6d), force-frequency relation (Figure 6e), or fatigability (Figure 6f) of the EDL muscle from B6.A/J mice.

\section{Discussion}

Despite over a century of research in the field of muscle injury and repair, there is still little understanding of the cellular mechanism involved in repairing injured myofibers. A decade ago, the discovery of dysferlin's role in the repair of injured myofibers offered the first suggestion that fusion of cellular vesicles is involved in the repair of injured muscle fibers. ${ }^{5}$ However, the identity of the vesicle responsible for mediating 
a

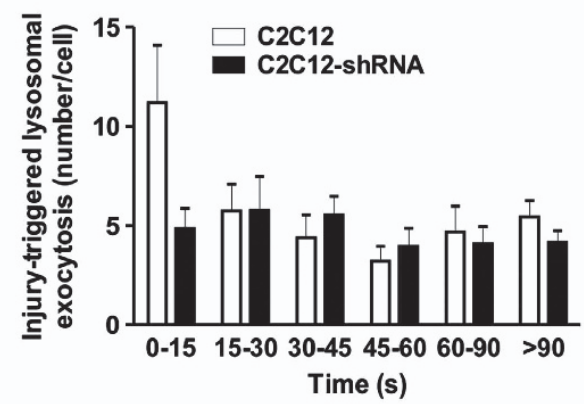

C

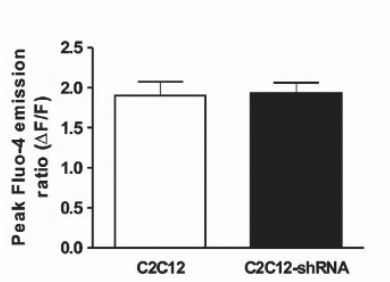

i

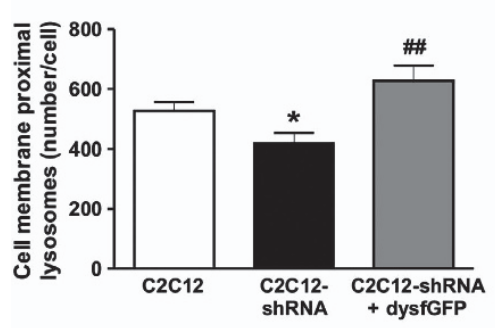

b

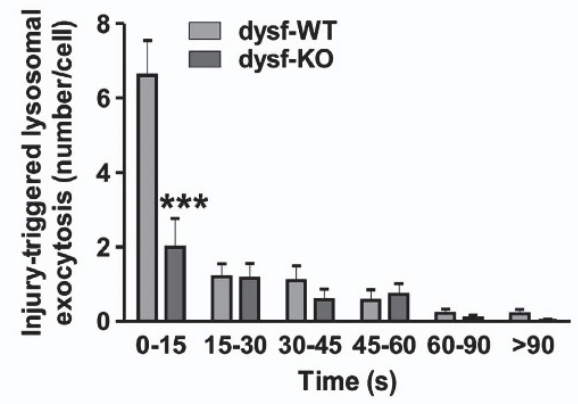

e

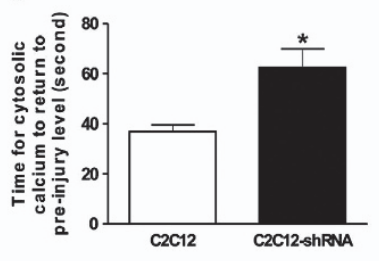

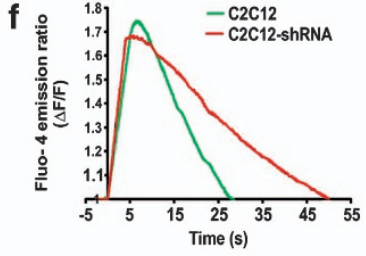
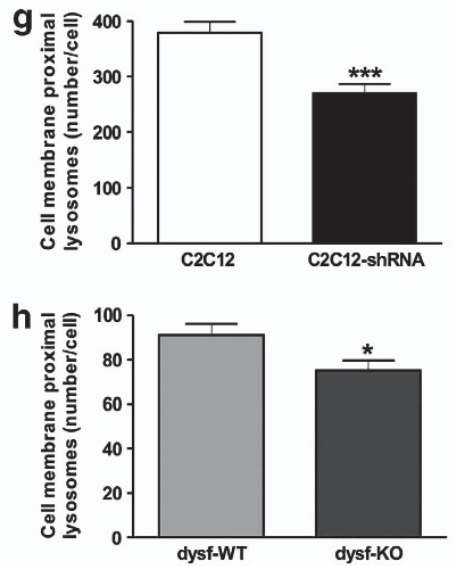

Figure 4 Dysferlin regulates tethering of lysosomes to the cell membrane and kinetics of injury-triggered lysosome exocytosis. (a and $\mathbf{b})$ Histogram showing averaged kinetics of lysosome exocytosis following laser injury ( $n \geq 10$ cells) in (a) C2C12 and (b) primary myoblasts. Note that it is only the earliest exocytic events that are reduced in dysferlinopathic myoblasts. (c) Quantification of the peak increase in Fluo-4 emission following laser injury in C2C12 and C2C12-shRNA myoblasts ( $n>7$ cells). (d) Time taken following laser injury for the Fluo-4 intensity to reach the peak value ( $n>7$ cells) in $\mathrm{C} 2 \mathrm{C} 12$ cells. (e) Time following laser injury for the increase in Fluo-4 intensity to return to pre-injury level ( $n>7$ cells). (f) Plot showing injury-triggered change in Fluo-4 intensity for a representative $\mathrm{C} 2 \mathrm{C} 12$ and C2C12-shRNA cell. ( $g$ and $\mathbf{h}$ ) Quantification of cell membrane-proximal lysosomes in (g) C2C12 and C2C12-shRNA and (h) dysf-WT and dysf-KO myoblasts ( $n \geq 20$ cells each), with fewer cell membrane-proximal lysosomes in dysferlinopathic cells. (i) Quantification of cell membrane-proximal lysosomes, showing that transient expression of dysferlin-GFP in C2C12-shRNA myoblasts ( $n=10$ ) increases the number of cell membrane-proximal lysosomes to a level similar to $\mathrm{C} 2 \mathrm{C} 12$. (j) Representative confocal image of a human myoblast immunolabeled for endogenous dysferlin (green) and LAMP1 (red), showing little lysosomal localization of dysferlin. (k) Confocal image of a C2C12 myoblast expressing dysferlin-GFP also shows lack of lysosomal localization of dysferlin. Scale bar: $10 \mu \mathrm{m}$. All data are means \pm S.E.M. ${ }^{*} P<0.05$ and ${ }^{* \star *} P<0.001$ for the comparison of mutant and corresponding WT samples; ${ }^{\# \#} P<0.01$ for the comparison to untransfected C2C12-shRNA; all compared by unpaired Student's $t$-test the repair of injured myofibers and the role that dysferlin has in this process have remained elusive. Understanding how injured myofibers undergo repair is not only crucial because muscle injury is widespread but also because the lack of this knowledge has hampered the development of therapies for muscular dystrophies, including LGMD2B, Miyoshi myopathy, LDMD2L, and dystroglycanopathies, all of which are associated with poor sarcolemmal membrane repair. ${ }^{5,23,44}$

Some of the effects of dysferlin deficiency on muscle tissue have been attributed to poor differentiation of the dysferlinopathic myoblasts. $^{4,32}$ The various mouse and human myoblast cell lines we have described here, although useful for studying the cell biological aspects of dysferlin deficiency in muscle cells in vitro, do not support a role for dysferlin deficiency in myoblast differentiation in culture. Thus, these cells are not suitable for testing any potential effect of dysferlin on muscle cell differentiation. However, our finding, across all these mouse and human cellular models, that dysferlin deficiency causes poor repair of dysferlinopathic myoblasts makes these cells an excellent model for screening drugs to improve the repair of dysferlinopathic muscle cell membranes. We also show that a lack of dysferlin results in delayed and reduced lysosome exocytosis as a result of poor tethering of lysosomes to the cell membrane (Figures 3 and 4). This reduced exocytosis may explain the subsarcolemmal vesicle accumulation reported in dysferlin-deficient muscles, ${ }^{45}$ and it 
a

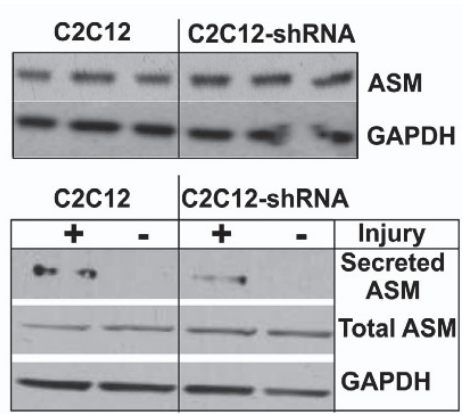

b

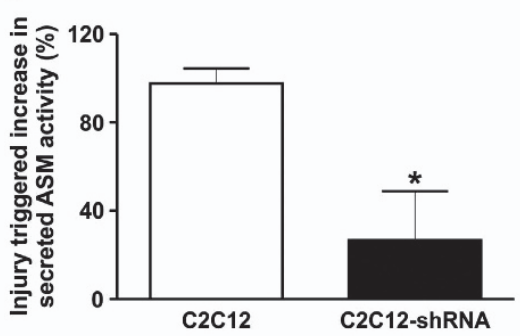

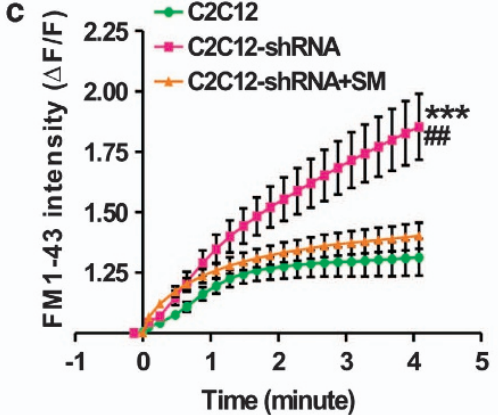

f
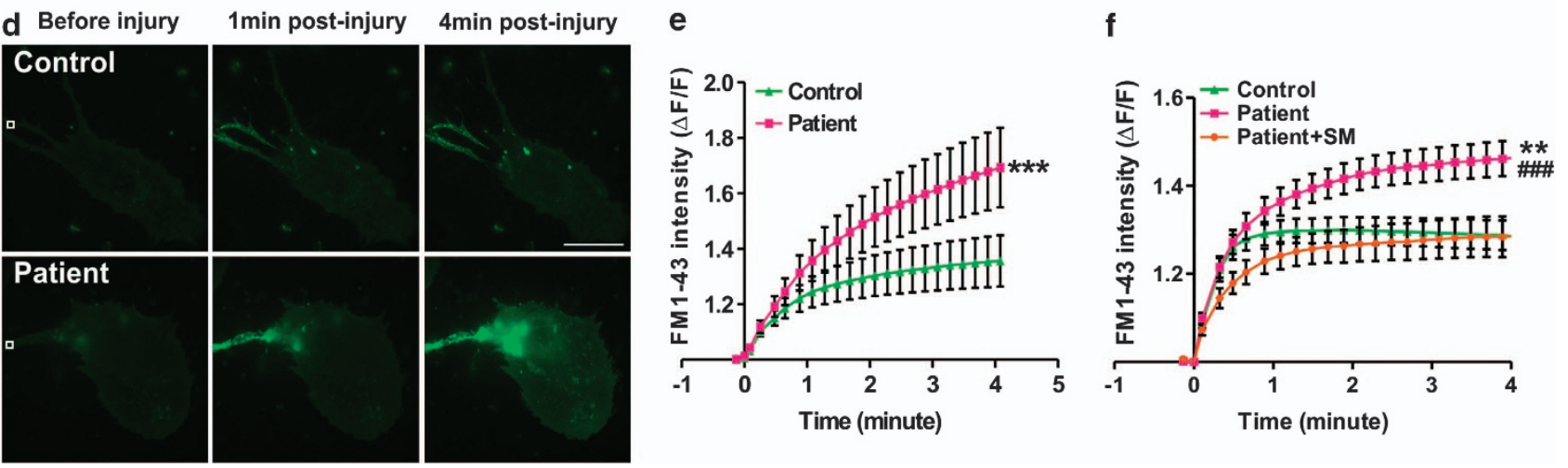

Figure 5 Reduced ASM secretion by dysferlinopathic cells and rescue of their repair ability by sphingomyelinase (SM) treatment. (a) Western blot for cellular ASM expression in three independent $\mathrm{C} 2 \mathrm{C} 12$ cultures (upper panel). Lower panel shows the same for a representative experiment in which the scrape injury-triggered secretion of ASM was compared in C2C12 and C2C12-shRNA cells. (b) Activity levels of secreted ASM after scrape injury of C2C12 and C2C12-shRNA myoblast cultures ( $n=4)$. (c) Quantification of FM1-43 influx following laser injury of C2C12 myoblasts and SM-treated and untreated C2C12-shRNA myoblasts ( $n=17$ cells each). Note the rescue of the repair deficit in C2C12-shRNA cells by SM treatment. (d) Time-lapse images and (e) quantification ( $n>16$ cells each) showing FM1-43 influx in control or LGMD2B patient myoblasts following focal laser injury, with poor repair of patient myoblasts. Scale bar: $100 \mu \mathrm{m}$. White box marks the injured region. (f) Quantification of FM1-43 influx following laser injury in control and SM-treated $(2 \mathrm{U} / \mathrm{ml})$ or untreated LGMD2B patient myoblasts ( $n>19$ myoblasts each), showing full rescue of the repair defect in patient myoblasts. Data are means \pm S.E.M. ${ }^{*} P<0.05$, ${ }^{* *} P<0.01$, and ${ }^{* * *} P<0.001$ (comparison of mutant and corresponding WT samples); ${ }^{\# \#} P<0.01$ and ${ }^{\# \# \#} P<0.001$ (treated versus untreated dysferlinopathic samples) compared by unpaired Student's $t$-test

is in agreement with the increased accumulation of lysosomes reported in dysferlinopathic muscle cells. ${ }^{4}$

Despite the requirement of dysferlin for cell membrane localization of lysosomes, we find that dysferlin itself is not localized to lysosomes. This supports previous reports that dysferlin is localized to the sarcolemma and T-tubules, ${ }^{46}$ but not to lysosomes. ${ }^{28}$ This also makes dysferlin similar to the cell membrane-localized synaptotagmin isoform, which regulate calcium-triggered vesicle tethering/fusion of the vesicle to the cell membrane by interacting with vesicular SNARES or synaptotagmins. ${ }^{47}$ Some of the dysferlininteracting molecules have been identified and include injury-sensing $^{48}$ and fusion-regulating proteins such as annexins. ${ }^{11}$ However, further work is needed to identify the SNAREs and lysosomal proteins that interact with dysferlin and facilitate lysosome docking and fusion to the injured cell membrane.

Through live imaging of lysosomes, we have shown here that lysosome-mediated sarcolemmal repair does not involve the proposed membrane patch model of cell membrane repair. Instead, lysosomes tethered to the cell membrane exocytose individually in response to injury, resulting in injury-triggered secretion of ASM. This process is compromised in the dysferlinopathic cells and is the basis for the poor repair of dysferlinopathic muscle. By demonstrating reduced lysosomal exocytosis and reduced
ASM secretion by dysferlinopathic muscle cells, our study offers direct evidence in support of a role for ASM secretion in the repair of mechanical injury to dysferlinopathic muscle cells and myofibers. The mechanism of this repair may involve endocytosis ${ }^{21,29}$ and bleb formation, ${ }^{30,41}$ which are proposed on the basis of pore-forming toxin-induced injury. However, it is worth noting that the repair of dysferlinopathic sarcolemma after pore-forming toxin-mediated injury is distinct from the repair after mechanical injury, as dysferlin-deficient muscle recovers normally from sarcolemmal damage caused by the cell membrane pore-forming plant metabolite saponin. ${ }^{49}$ Other effects of ASM could be mediated by its ability to hydrolyze cell membrane sphingomyelin. This hydrolysis would result in the formation of membrane microdomains, which can regulate signaling, fluidity, and cytoskeleton organization at the cell membrane ${ }^{50,51}$ processes that regulate membrane properties and cell membrane repair. ${ }^{52,53}$ In agreement with a role for membrane properties in the repair of injured membranes, we recently observed that the use of a membrane-active steroid analog improves the repair of injured cell membranes. ${ }^{54}$ Thus, additional work is needed to elucidate the complete sequence of steps by which reduced ASM secretion following mechanical injury results in poor repair of dysferlinopathic muscle.

Beyond regulating sarcolemmal properties and sarcolemmal repair, ASM can also aid in the repair of injured 

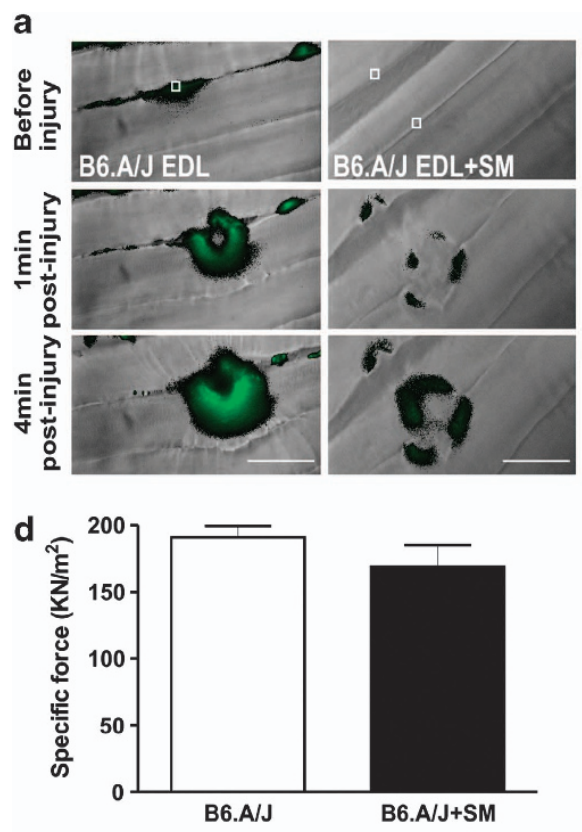

b

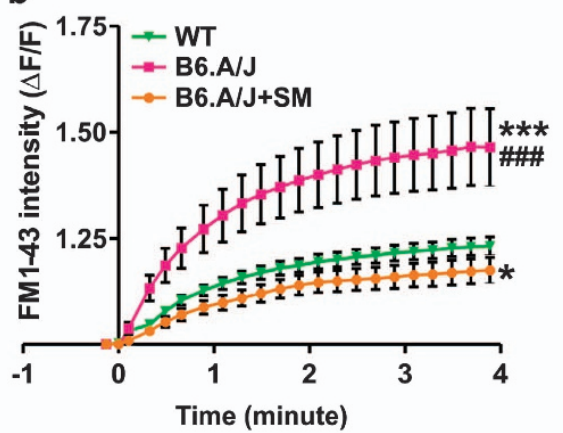

e

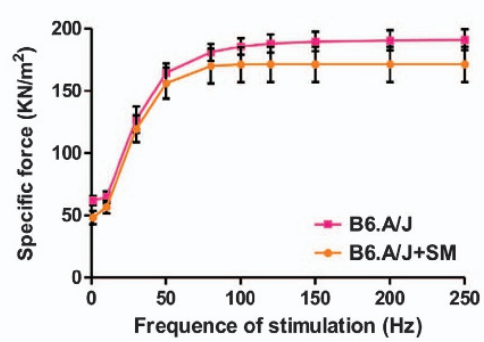

c
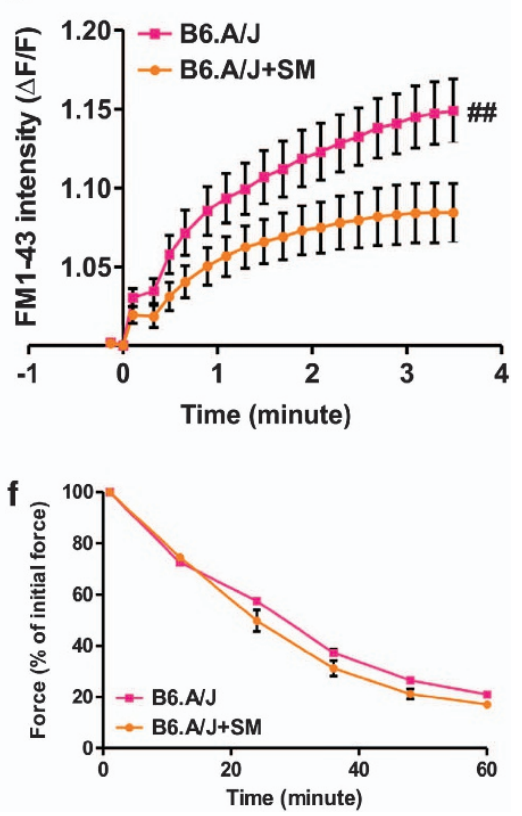

Figure 6 Sphingomyelinase (SM) treatment rescues the repair ability of dysferlinopathic myofibers without affecting their contractile force. (a) Time-lapse images and (b) quantification of FM1-43 influx, following laser injury, into SM $(0.5 \mathrm{U} / \mathrm{ml})$-treated and untreated EDL myofibers $(n=15)$ isolated from healthy $(\mathrm{C} 57 \mathrm{BL} / 6)$ and dysferlinopathic (B6.A/J) mice. Treatment of dysferlinopathic myofibers with SM $(0.5 \mathrm{U} / \mathrm{ml})$ fully rescued the sarcolemmal repair deficit. Scale bar: $50 \mu \mathrm{m}$. White box marks the region injured by the laser. (c) Quantification of FM1-43 influx following laser injury into SM-treated and untreated biceps myofibers $(n>14)$ isolated from dysferlinopathic (B6.A/J) mice. (d) Specific force of SM-treated and untreated dysferlinopathic EDL $(n=5)$ muscle from B6.A/J. (e) Frequency-force curve of SM-treated and untreated dysferlinopathic EDL $(n=5)$ muscle from B6.A/J. (f) Fatigue characteristics $(n>5)$ of SM-treated or untreated dysferlinopathic EDL muscle from B6.A/J. Data are means \pm S.E.M. ${ }^{*} P<0.05$ and ${ }^{* * *} P<0.001$ (comparison of mutant and corresponding WT samples); ${ }^{\# \#} P<0.01$ and ${ }^{\# \# \#} P<0.001$ (treated versus untreated dysferlinopathic samples); all compared by unpaired Student's $t$-test

muscle tissue through its other roles in reducing muscle contractile force and the calcium sensitivity of the muscle contractile apparatus. ${ }^{42}$ This role of ASM could protect the injured muscle by reducing the potential for contractioninduced re-injury. Also, the ASM-ceramide system can regulate inflammation by regulating the release of pro-inflammatory cytokines. ${ }^{55}$ Finally, by increasing basal and insulin-induced glucose uptake in skeletal muscles, ${ }^{56}$ ASM can increase metabolism and aid the recovery of injured muscle cells. Dysferlin deficiency could affect one or more of the abovementioned benefits of injury-triggered ASM secretion. Thus, in addition to the myofiber repair deficit, reduction in these effects of ASM could further contribute to poor repair of dysferlinopathic muscles. Thus, our results not only identify the cellular mechanism underlying the poor repair of dysferlinopathic muscle but also point to novel aspects of dysferlin deficit on muscle repair.

Our finding that acute SM treatment is sufficient to improve the repair ability of the dysferlinopathic myofibers demonstrates its potential as a therapy for dysferlinopathy. Deleterious effect of long-term SM treatment on muscle function is a source of some concern. ${ }^{42}$ However, our findings that acute treatment with SM does not negatively affect muscle contractility and excitation contraction coupling together with the known rapid ASM washout kinetics in vivo ${ }^{43}$ alleviate this potential confounding factor. In addition, there has been significant progress made in preclinical and clinical trials aimed at ASM-based therapy for another rare genetic disorder, Niemann-Pick syndrome. ${ }^{57}$ In view of these,
ASM treatment is as a therapeutic option that could be evaluated for its clinical efficacy for dysferlinopathic patients.

\section{Materials and Methods}

Cell culture. The stable C2C12-shRNA mouse clone was derived from a C2C12 dysferlin shRNA pool, as described elsewhere. ${ }^{31}$ Immortalized mouse primary cells, dysf-WT and dysf-KO, were a gift from Dr Terry Partridge and were derived from EDL fibers as described previously. ${ }^{32}$ Human cells were isolated from the quadriceps muscle of a dysferlinopathic 17-year-old male with a homozygous mutation in exon 44 that resulted in a c.4882G > A mutation; they were a gift from Dr Eduardo Gallardo. Control myoblasts were isolated from the pectoralis major muscle of a 41-year-old male. For cell doubling-time calculations, cells cultured thrice in triplicate were harvested and counted on each day of culture, and these cell numbers were used to determine the culture's doubling time.

SM treatment of cells. Cells cultured on coverslips were pre-incubated for 20 min with $2 \mathrm{U} / \mathrm{ml}$ of Bacillus SM (Sigma-Aldrich, St. Louis, MO, USA) in growth medium and then laser-injured in cell imaging medium (CIM: HBSS with $10 \mathrm{mM}$ HEPES, pH 7.4) containing $1 \mu \mathrm{g} / \mu \mathrm{l}$ FM1-43 dye and $2 \mathrm{U} / \mathrm{ml}$ of SM as described below.

Transfection of dysf-GFP plasmid. C2C12 or C2C12-shRNA myoblasts were transfected with dysf-GFP using Lipofectamine LTX (Life Technologies, Carlsbad, CA, USA) for 24-48 h.

Western blotting and immunostaining. Cells were lysed with RIPA buffer (Sigma-Aldrich) containing protease inhibitor cocktail (Fisher Scientific, Waltham, MA, USA) or fixed with $4 \%$ paraformaldehyde (PFA), then permeabilized with $0.1 \%$ Triton $X-100$. Proteins transferred to nitrocellulose membranes were probed with the indicated antibodies against: ASM (Abcam, Cambridge, MA, USA), desmin (Santa Cruz, Dallas, TX, USA), dysferlin (Novocastra, Buffalo Grove, IL, USA), myogenin (Dako, Carpinteria, CA, USA), GAPDH (Santa Cruz), myosin heavy chain 3 (Developmental Studies Hybridoma Bank, 
lowa City, IA, USA), and $\alpha$-actinin (Epitomics, Burlingame, CA, USA). Primary antibodies were followed by the appropriate HRP-conjugated secondary antibodies (Sigma-Aldrich), and chemiluminescent western blotting substrate (Fisher, Waltham, MA, USA; GE Healthcare, Pittsburgh, PA, USA) then processed on Bio-Lite X-ray film (Denville Scientific, Metuchen, NJ, USA). For immunostaining, permeabilized cells were reacted with anti-dysferlin (Epitomics) and anti-LAMP1 (Santa Cruz) antibodies, followed by fluorophore-conjugated secondary antibodies: Alexa Fluor 488-anti-rabbit, Alexa Fluor 594-anti-rat, and Alexa Fluor 594-anti-mouse (Life Technologies). Nuclei were counterstained with Hoechst 33342. After mounting in mounting medium (Dako), cells were imaged as described in Supplementary Methods.

PCR genotyping. Total DNA was isolated from dysf-WT and dysf-KO immortalized mouse primary cells and used for genotyping. The primers used to identify the dysferlin mutation (A/J Etn insertion in intron 4) in dysf-WT and -KO cells were: dysf-F, $\quad 5^{\prime}$-TTCCTCTCTTGTCGGTCTAG-3'; dysf-R, 5'-CTTCACTGGG AAGTATGTCG-3'; ETn-oR, 5'-GCCTTGATCAGAGTAACTGTC-3', as described previously. ${ }^{6}$ To assess the status of the dysferlin allele, genomic DNA was PCRamplified using Dysf (dysf-F and dysf-R) primers, resulting in the amplification of a 207-bp fragment for the dysferlin allele, not disrupted by the Etn transposon sample (dysf-WT). A lack of this band indicates ETn transposon insertion in the dysferlin allele (dysf-KO). Independently, to establish ETn insertion, genomic DNA was PCRamplified using ETn-oR and dysf-R primers, resulting in a 234-bp fragment for the allele that contains the ETn insertion and no amplification of the dysf-WT allele.

Injury assays. These assays were performed as described previously and listed below. ${ }^{33}$

Glass bead injury. Cells cultured on coverslips were transferred to CIM or PBS (Sigma-Aldrich) containing $2 \mathrm{mg} / \mathrm{ml}$ of lysine-fixable FITC-dextran (Life Technologies). Cells were injured by rolling glass beads (Sigma-Aldrich) over the cells. They were allowed to heal at $37^{\circ} \mathrm{C}$ for $5 \mathrm{~min}$, and then incubated at $37^{\circ} \mathrm{C}$ for $5 \mathrm{~min}$ in CIM/PBS buffer containing $2 \mathrm{mg} / \mathrm{ml}$ of lysine-fixable TRITCdextran (Life Technologies). Cells were fixed in 4\% PFA, and nuclei were counterstained with Hoechst 33342 ; the cells were then mounted in fluorescence mounting medium (Dako) and imaged as described in Supplementary Methods. The number of FITC-positive cells (injured and repaired) and TRITC-positive cells (injured and not repaired) were counted. The number of injured cells that failed to be repaired was expressed as a percentage of the total injured cells.

Laser injury. Cells cultured on coverslips were transferred to and incubated in CIM/PBS buffer with $1 \mu \mathrm{g} / \mu \mathrm{l}$ FM1-43 dye (Life Technologies) and placed in a Tokai Hit microscopy stage-top ZILCS incubator (Tokai Hit Co., Fujinomiya-shi, Japan) maintained at $37^{\circ} \mathrm{C}$. For laser injury, a $1-$ to $5-\mu \mathrm{m}^{2}$ area was irradiated for $<10 \mathrm{~ms}$ with a pulsed laser (Ablate!, 3i Intelligent Imaging Innovations, Inc. Denver, CO, USA). Cells were imaged at $2 \mathrm{~s}$ intervals using a IX81 Olympus microscope (Olympus America, Center Valley, PA, USA) as described in Supplementary Methods. FM dye intensity ( $\triangle F / F$ where $F$ is the original value) was used to quantify the kinetics of cell membrane repair and represented with intervals of five frames.

Monitoring injury triggered changes in cell-surface LAMP1 levels. Changes were monitored as described previously. ${ }^{33}$ Cells cultured on coverslips were injured as described above by rolling of glass beads in the presence of lysine-fixable TRITC-dextran. After allowing repair to occur for $5 \mathrm{~min}$ a $37^{\circ} \mathrm{C}$ and blocking with $3 \% \mathrm{BSA}$ (in CIM) for $10 \mathrm{~min}$ at $4{ }^{\circ} \mathrm{C}$, cell-surface LAMP1 was immunolabeled for $30 \mathrm{~min}$ at $4{ }^{\circ} \mathrm{C}$ using antibody specific for the lumina domain of LAMP1 (Santa Cruz) in blocking solution, followed by labeling with Alexa Fluor 488-anti-rat antibody (Life Technologies) for $15 \mathrm{~min}$ at $4{ }^{\circ} \mathrm{C}$. Cells fixed in 4\% PFA were stained with Hoechst 33342 and imaged as described in Supplementary Methods. The increase in cell-surface LAMP1 staining intensity of individual injured (TRITC-positive) cells was normalized to the average cell-surface LAMP1 staining intensity of all (>125) uninjured (TRITC-negative) cells. The percentage increase in cell-surface LAMP1 staining for each injured cell was then determined (divided by the average value for the uninjured cells). This percentage increase was then averaged for all the injured cells (>400 measured).

Live imaging of cell membrane injury-triggered lysosomes. Cells were subjected to the live imaging of cell membrane injury-triggered lysosome assay as described. ${ }^{33}$ Cultured cells on coverslips were incubated overnight with growth medium containing $2 \mathrm{mg} / \mathrm{ml}$ of fluorescent-dextran. The cells were then washed and incubated for $2 \mathrm{~h}$ with growth medium; following laser injury, they were imaged with TIRF as described in Supplementary Methods. The number of lysosomes $/ \mu \mathrm{m}^{2}$ (exocytic or proximal) was counted for each cell, and the value presented is that for the average area occupied by C2C12 myoblasts $\left(3000 \mu \mathrm{m}^{2}\right)$ or primary myoblasts $\left(1200 \mu \mathrm{m}^{2}\right)$.

Imaging $\mathrm{Ca}^{2+}$ influx into cells after laser injury. $\mathrm{C} 2 \mathrm{C} 12$ and $\mathrm{C} 2 \mathrm{C} 12-$ shRNA cells cultured on coverslips were incubated with DMEM without FBS that contained $10 \mu \mathrm{M}$ Fluo-4-AM (Life Technologies) for $20 \mathrm{~min}$ at $37^{\circ} \mathrm{C}$ and $5 \% \mathrm{CO}_{2}$. After washing with pre-warmed $\mathrm{CIM}$, the cells were laser injured in $\mathrm{CIM}$ as described above and imaged at 4-6 frames/s. The kinetics of $\mathrm{Ca}^{2+}$ influx was measured as the ratio of cellular Fluo-4-AM emission ( $\Delta F / F$, where $F$ is the Fluo-4 intensity before injury). Images show this intensity ratio, generated using Metamorph7.0 (Molecular Devices, Sunnyvale, CA, USA).

ASM enzyme assay. $\mathrm{C} 2 \mathrm{C} 12$ or $\mathrm{C} 2 \mathrm{C} 12$-shRNA was washed and incubated with $\mathrm{Ca}^{2+}$-free PBS for $10 \mathrm{~min}$ at $37^{\circ} \mathrm{C}$. Cells were then injured (or not) by scraping in prewarmed $\mathrm{CIM}$ and incubated for $5 \mathrm{~min}$ to repair at $37^{\circ} \mathrm{C}$. After repair, the culture media was collected, and cell lysates prepared as described before. The Amplex Red sphingomyelinase assay kit (Life Technologies) was used to assess ASM activity in the culture supernatants and cell lysates. For each sample, the secreted ASM activity was normalized to the activity in the lysate. Activity following injury was expressed as a percentage increase compared with the no-injury sample.

Fibers isolation, membrane injury, and SM treatment. Methods involving animals were approved by the local institutional animal research committee, and animals were maintained in a facility accredited by the American Association for Accreditation of Laboratory Animal Care. EDL muscle was surgically isolated from euthanized 3-month-old $\mathrm{C} 57 \mathrm{BL} / 6$ or B6.A/J mice in Tyrode's solution containing $128 \mathrm{mM} \mathrm{NaCl}, 4.7 \mathrm{mM} \mathrm{KCl}, 1.36 \mathrm{mM} \mathrm{CaCl}_{2}, 20 \mathrm{mM}$ $\mathrm{NaHCO}_{3}, 0.36 \mathrm{mM} \mathrm{NaH}_{2} \mathrm{PO}_{4}, 1 \mathrm{mM} \mathrm{MgCl}$, and $10 \mathrm{mM}$ glucose (pH 7.4), and biceps muscle was surgically isolated from euthanized 7-month-old B6.A/J mice in Tyrode's solution. Laser injury was carried out as described above in the Tyrode's buffer containing $1.33 \mu \mathrm{g} / \mu \mathrm{l}$ FM1-43 dye. The kinetics of repair were determined by measuring the cellular FM1-43 dye fluorescence. For SM treatment, freshly isolated muscle was laser injured as described above but in the presence of $0.5 \mathrm{U} / \mathrm{ml}$ of Bacillus SM (Sigma-Aldrich), added before injury.

Skeletal muscle contractile properties measured in vitro. Mice (7month-old B6.A/J and 3-month-old C57BL/6) were anesthetized with an intraperitoneal injection of ketamine $(100 \mathrm{mg} / \mathrm{kg})$ and xylazine $(10 \mathrm{mg} / \mathrm{kg})$. After the EDL muscle was exposed, 5-0 silk sutures were tied securely to the distal and proximal tendons. The muscle was then carefully removed from the mouse and placed vertically in a bath containing buffered mammalian Ringer's solution (composition in mM: $137 \mathrm{NaCl}, 24 \mathrm{NaHCO}_{3}, 11$ glucose, $5 \mathrm{KCl}, 2 \mathrm{CaCl}_{2}$, $1 \mathrm{MgSO}_{4}, 1 \mathrm{NaH}_{2} \mathrm{PO}_{4}$, and 0.025 turbocurarine chloride). The distal tendon was attached to a fixed bottom plate and the proximal tendon to the arm of a dual servomotor (Aurora Scientific, Aurora, ON, Canada, model 305B). The temperature of the Ringer's solution was maintained at $25^{\circ} \mathrm{C}$ and bubbled with $95 \% \mathrm{O}_{2}-5 \% \mathrm{CO}_{2}$. The EDL muscle was stimulated between two stainless steel plate electrodes flanking the muscle. The voltage of single $0.2-\mathrm{ms}^{2}$ stimulation pulses was increased until supramaximal stimulation of the muscle was achieved. Subsequently, muscle length was adjusted to the length that resulted in maximal twitch force (i.e., optimal length for force generation). With the muscle held at optimal length, the force developed during trains of stimulation pulses (i.e., tetanic contraction) was recorded. The stimulation frequency was increased in intervals of 2-min steps of 30 and $20 \mathrm{~Hz}(30,50,80,100,120,150,180,200,220$, and $250 \mathrm{~Hz}$ ) till the maximal isometric tetanic force (plateau) was achieved. For the EDL muscle, 300-ms trains of pulses were used, separated by 2 min of rest. SM was then added to the Ringer's solution $(0.5 \mathrm{U} / \mathrm{ml})$, and the same muscle was stimulated with increases in steps of 30 and $20 \mathrm{~Hz}$ till the maximal isometric force was repeated. Finally, the fatigue response of the muscle, exposed to SM, was measured with 60 isometric contractions, once every $5 \mathrm{~s}$, and compared with that of B6.A/J mouse muscles fatigued in Ringer's solution. The stimulation duration of each contraction was $400 \mathrm{~ms}$. The muscle length was measured with calipers, and the optimal fiber length was calculated by multiplying the optimal muscle length by 0.45 , an established fiber length/muscle length ratio for EDL muscle. ${ }^{58}$ The muscle 
mass was weighed after removal of the muscle from the bath. The muscle-specific force, a measure of intrinsic force generation of muscle, was calculated using the maximal isometric force, the muscle mass, and the fiber length according the following equation: specific force $=$ maximal isometric force/(muscle mass $\times$ (density of muscle tissue * fiber length) ${ }^{-1}$ ). Muscle tissue density is $1.056 \mathrm{~kg} / \mathrm{l}$. For the fatigue protocol, the force for the first concentration was set at $100 \%$, and the force measured at $1,2,3,4$, and 5 min was compared with the first value and expressed as percentages.

\section{Conflict of Interest}

The authors declare no conflict of interest.

Acknowledgements. This work was funded by grants from the NIH/NIAMS (AR055686, HD040677, AR060836) and MDA (MDA277389) to JKJ, and from the AFM to AD. KN is supported by the NIH (K26OD011171; R24HD050846), the MDA (translational grant), and the US Department of Defense (W81XWH-05-1-0659, W81XWH-11-1-0782, W81XWH-11-1-0330) grants. Drs Terry Partridge and Jonathan Cohen generated the pool of dys-WT and dysf-KO immortomouse myoblasts from which the clone used here was identified. Dr Isabelle Richard provided the B6.A/J mice, and Dr Eduardo Gallardo provided the patient biopsy. $A B$ generated the immortalized human cells using the platform for immortalization of human cells at the Institut de Myologie, Paris. RBa generated the C2C12-shRNA cells with funding from Jain Foundation. We thank Dr Deborah McClellan for editorial assistance. JKJ and $\mathrm{AD}$ designed the study, analyzed data, and wrote the paper. AD performed all experiments, with help from RBh with the glass bead-injury experiments. JHVdM performed the EDL force measurements, and KN assisted in data analysis and writing the paper.

1. Bashir R, Britton S, Strachan T, Keers S, Vafiadaki E, Lako $M$ et al. A gene related to Caenorhabditis elegans spermatogenesis factor fer-1 is mutated in limb-girdle muscular dystrophy type 2B. Nat Genet 1998; 20: 37-42.

2. Liu J, Aoki M, Illa I, Wu C, Fardeau M, Angelini C et al. Dysferlin, a novel skeletal muscle gene, is mutated in Miyoshi myopathy and limb girdle muscular dystrophy. Nat Genet 1998; 20: $31-36$.

3. Cenacchi G, Fanin M, De Giorgi LB, Angelini C. Ultrastructural changes in dysferlinopathy support defective membrane repair mechanism. J Clin Pathol 2005; 58: 190-195.

4. Demonbreun AR, Fahrenbach JP, Deveaux K, Earley JU, Pytel P, McNally EM. Impaired muscle growth and response to insulin-like growth factor 1 in dysferlin-mediated muscular dystrophy. Hum Mol Genet 2011; 20: 779-789.

5. Bansal D, Miyake K, Vogel SS, Groh S, Chen CC, Williamson R et al. Defective membrane repair in dysferlin-deficient muscular dystrophy. Nature 2003; 423: 168-172.

6. Ho M, Post CM, Donahue LR, Lidov HG, Bronson RT, Goolsby H et al. Disruption of muscle membrane and phenotype divergence in two novel mouse models of dysferlin deficiency. Hum Mol Genet 2004; 13: 1999-2010.

7. Gallardo E, Rojas-Garcia R, de LN, Pou A, Brown Jr RH, Illa I. Inflammation in dysferlin myopathy: immunohistochemical characterization of 13 patients. Neurology 2001; 57 : 2136-2138.

8. Bonnemann CG, McNally EM, Kunkel LM. Beyond dystrophin: current progress in the muscular dystrophies. Curr Opin Pediatr 1996; 8: 569-582.

9. Lek A, Evesson FJ, Sutton RB, North KN, Cooper ST. Ferlins: regulators of vesicle fusion for auditory neurotransmission, receptor trafficking and membrane repair. Traffic 2012; 13: 185-194.

10. Posey Jr AD, Demonbreun A, McNally EM. Ferlin proteins in myoblast fusion and muscle growth. Curr Top Dev Biol 2011; 96: 203-230.

11. Lennon NJ, Kho A, Bacskai BJ, Perlmutter SL, Hyman BT, Brown Jr RH. Dysferlin interacts with annexins $A 1$ and $A 2$ and mediates sarcolemmal wound-healing. J Biol Chem 2003; 278: 50466-50473.

12. Kesari A, Fukuda M, Knoblach S, Bashir R, Nader GA, Rao D et al. Dysferlin deficiency shows compensatory induction of Rab27A/SIp2a that may contribute to inflammatory onset. Am J Pathol 2008; 173: 1476-1487.

13. Nagaraju K, Rawat R, Veszelovszky E, Thapliyal R, Kesari A, Sparks S et al. Dysferlin deficiency enhances monocyte phagocytosis: a model for the inflammatory onset of limbgirdle muscular dystrophy 2B. Am J Pathol 2008; 172: 774-785.

14. de Luna N, Gallardo E, Soriano M, Dominguez-Perles R, de la Torre C, Rojas-Garcia R et al. Absence of dysferlin alters myogenin expression and delays human muscle differentiation 'in vitro'. J Biol Chem 2006; 281: 17092-17098.

15. Humphrey GW, Mekhedov E, Blank PS. de MA, Pekkurnaz G, Nagaraju K et al. GREG cells, a dysferlin-deficient myogenic mouse cell line. Exp Cell Res 2012; 318: 127-135.

16. Philippi S, Bigot A, Marg A, Mouly V, Spuler S, Zacharias U. Dysferlin-deficient immortalized human myoblasts and myotubes as a useful tool to study dysferlinopathy. PLOS Curr 2012; 4: RRN1298.
17. Millay DP, Maillet M, Roche JA, Sargent MA, McNally EM, Bloch RJ et al. Genetic manipulation of dysferlin expression in skeletal muscle: novel insights into muscular dystrophy. Am J Pathol 2009; 175: 1817-1823.

18. Lostal W, Bartoli M, Bourg N, Roudaut C, Bentaib A, Miyake K et al. Efficient recovery of dysferlin deficiency by dual adeno-associated vector-mediated gene transfer. Hum Mol Genet 2010; 19: 1897-1907.

19. Han R. Muscle membrane repair and inflammatory attack in dysferlinopathy. Skelet Muscle 2011; $1: 10$.

20. Borgonovo B, Cocucci E, Racchetti G, Podini P, Bachi A, Meldolesi J. Regulated exocytosis: a novel, widely expressed system. Nat Cell Biol 2002; 4: 955-962.

21. Corrotte M, Almeida PE, Tam C, Castro-Gomes T, Fernandes MC, Millis BA et al. Caveolae internalization repairs wounded cells and muscle fibers. Elife 2013; 2: 000926.

22. Sharma N, Medikayala S, Defour A, Rayavarapu S, Brown KJ, Hathout $Y$ et al. Use of quantitative membrane proteomics identifies a novel role of mitochondria in healing injured muscles. J Biol Chem 2012; 287: 30455-30467.

23. Jaiswal JK, Marlow G, Summerill G, Mahjneh I, Mueller S, Hill M et al. Patients with a nondysferlin miyoshi myopathy have a novel membrane repair defect. Traffic 2007; 8: 77-88.

24. Han WQ, Xia M, Xu M, Boini KM, Ritter JK, Li NJ et al. Lysosome fusion to the cell membrane is mediated by the dysferlin C2A domain in coronary arterial endothelial cells. J Cell Sci 2012; 125: 1225-1234.

25. McNeil PL, Kirchhausen T. An emergency response team for membrane repair. Nat Rev Mol Cell Biol 2005; 6: 499-505.

26. McNeil PL, Terasaki M. Coping with the inevitable: how cells repair a torn surface membrane. Nat Cell Biol 2001; 3: E124-E129.

27. McNeil PL. Repairing a torn cell surface: make way, lysosomes to the rescue. J Cell Sci 2002; 115: 873-879.

28. McDade JR, Michele DE. Membrane damage-induced vesicle-vesicle fusion of dysferlincontaining vesicles in muscle cells requires microtubules and kinesin. Hum Mol Genet 2013; 23: 1677-1686.

29. Tam C, Idone V, Devlin C, Fernandes MC, Flannery A, He X et al. Exocytosis of acid sphingomyelinase by wounded cells promotes endocytosis and plasma membrane repair. J Cell Biol 2010; 189: 1027-1038.

30. Draeger A, Babiychuk EB. Ceramide in plasma membrane repair. Handb Exp Pharmacol 2013 341-353.

31. Belanto JJ, Diaz-Perez SV, Magyar CE, Maxwell MM, Yilmaz Y, Topp K et al. Dexamethasone induces dysferlin in myoblasts and enhances their myogenic differentiation. Neuromuscul Disord 2010; 20: 111-121.

32. Cohen TV, Cohen JE, Partridge TA. Myogenesis in dysferlin-deficient myoblasts is inhibited by an intrinsic inflammatory response. Neuromuscul Disord 2012; 22: 648-658.

33. Defour A, Sen Chandra S, Jaiswal JK. Imaging cell membrane injury and sub-cellular processes involved in repair. J Vis Exp 2014; e-pub ahead of print 24 March 2014; doi:10.3791/51106.

34. Reddy A, Caler EV, Andrews NW. Plasma membrane repair is mediated by $\mathrm{Ca}(2+)$ regulated exocytosis of lysosomes. Cell 2001; 106: 157-169.

35. Jaiswal JK, Andrews NW, Simon SM. Membrane proximal lysosomes are the major vesicles responsible for calcium-dependent exocytosis in nonsecretory cells. J Cell Biol 2002; 159: 625-635.

36. Jaiswal JK, Chakrabarti S, Andrews NW, Simon SM. Synaptotagmin VII restricts fusion pore expansion during lysosomal exocytosis. PLOS Biol 2004; 2: E233.

37. Glover L, Brown RH Jr. Dysferlin in membrane trafficking and patch repair. Traffic 2007; 8: 785-794.

38. Chapman ER. How does synaptotagmin trigger neurotransmitter release? Annu Rev Biochem 2008; 77: 615-641.

39. Kerr JP, Ziman AP, Mueller AL, Muriel JM, Kleinhans-Welte E, Gumerson JD et al. Dysferlin stabilizes stress-induced $\mathrm{Ca} 2+$ signaling in the transverse tubule membrane. Proc Natl Acad Sci USA 2013; 110: 20831-20836.

40. Krahn M, Wein N, Bartoli M, Lostal W, Courrier S, Bourg-Alibert N et al. A naturally occurring human minidysferlin protein repairs sarcolemmal lesions in a mouse model of dysferlinopathy. Sci Transl Med 2010; 2: 50ra69.

41. Babiychuk EB, Monastyrskaya K, Potez S, Draeger A. Blebbing confers resistance against cell lysis. Cell Death Differ 2011; 18: 80-89.

42. Ferreira LF, Moylan JS, Stasko S, Smith JD, Campbell KS, Reid MB. Sphingomyelinase depresses force and calcium sensitivity of the contractile apparatus in mouse diaphragm muscle fibers. J Appl Physiol (1985) 2012; 112: 1538-1545.

43. Garnacho C, Dhami R, Simone E, Dziubla T, Leferovich J, Schuchman EH et al. Delivery of acid sphingomyelinase in normal and niemann-pick disease mice using intercellular adhesion molecule-1-targeted polymer nanocarriers. J Pharmacol Exp Ther 2008; 325: $400-408$.

44. Han R, Kanagawa M, Yoshida-Moriguchi T, Rader EP, Ng RA, Michele DE et al. Basal lamina strengthens cell membrane integrity via the laminin $G$ domain-binding motif of alpha-dystroglycan. Proc Natl Acad Sci USA 2009; 106: 12573-12579.

45. Selcen D, Stilling G, Engel AG. The earliest pathologic alterations in dysferlinopathy. Neurology 2001; 56: 1472-1481.

46. Klinge L, Laval S, Keers S, Haldane F, Straub V, Barresi R et al. From T-tubule to sarcolemma: damage-induced dysferlin translocation in early myogenesis. FASEB J 2007; 21: $1768-1776$. 
47. Sudhof TC. Synaptotagmins: why so many? J Biol Chem 2002; 277: 7629-7632.

48. Cai C, Masumiya H, Weisleder N, Matsuda N, Nishi M, Hwang M et al. MG53 nucleates assembly of cell membrane repair machinery. Nat Cell Biol 2009; 11 : 56-64.

49. Zhao P, Xu L, Ait-Mou Y, de Tombe PP, Han R. Equal force recovery in dysferlin-deficient and wild-type muscles following saponin exposure. J Biomed Biotechnol 2011; 2011: 235216.

50. van Blitterswijk WJ, van der Luit AH, Veldman RJ, Verheij M, Borst J. Ceramide: second messenger or modulator of membrane structure and dynamics? Biochem $\mathrm{J} 2003 ; 369$ : 199-211.

51. Grassme H, Jendrossek V, Bock J, Riehle A, Gulbins E. Ceramide-rich membrane rafts mediate CD40 clustering. J Immunol 2002; 168: 298-307.

52. McNeil PL, Steinhardt RA. Plasma membrane disruption: repair, prevention, adaptation. Annu Rev Cell Dev Biol 2003; 19: 697-731.

53. Jaiswal JK, Lauritzen SP, Scheffer L, Sakaguchi M, Bunkenborg J, Simon SM et al. S100A11 is required for efficient plasma membrane repair and survival of invasive cancer cells. Nat Commun 2014; 5: 3795.

54. Heier CR, Damsker JM, Yu Q, Dillingham BC, Huynh T, Van der Meulen JH et al. VBP15, a novel anti-inflammatory and membrane-stabilizer, improves muscular dystrophy without side effects. EMBO Mol Med 2013; 5: 1569-1585.

55. Grassme H, Becker KA, Zhang Y, Gulbins E. Ceramide in bacterial infections and cystic fibrosis. Biol Chem 2008; 389: 1371-1379.
56. Turinsky J, Nagel GW, Elmendorf JS, Damrau-Abney A, Smith TR. Sphingomyelinase stimulates 2-deoxyglucose uptake by skeletal muscle. Biochem $J$ 1996; 313(Pt 1): 215-222.

57. Schuchman EH. The pathogenesis and treatment of acid sphingomyelinase-deficient Niemann-Pick disease. J Inherit Metab Dis 2007; 30: 654-663.

58. Brooks SV, Faulkner JA. The magnitude of the initial injury induced by stretches of maximally activated muscle fibres of mice and rats increases in old age. J Physiol 1996; 497(Pt 2): 573-580

(c) (i) () $\Theta$ Cell Death and Disease is an open-access journal published by Nature Publishing Group. This work is licensed under a Creative Commons Attribution-NonCommercialNoDerivs 3.0 Unported License. The images or other third party material in this article are included in the article's Creative Commons license, unless indicated otherwise in the credit line; if the material is not included under the Creative Commons license, users will need to obtain permission from the license holder to reproduce the material. To view a copy of this license, visit http://creativecommons.org/ licenses/by-nc-nd/3.0/

Supplementary Information accompanies this paper on Cell Death and Disease website (http://www.nature.com/cddis) 